Human Journals

Research Article

June 2020 Vol.:15, Issue:4

(C) All rights are reserved by Ruth Gontse et al.

\title{
Determination of Mineral Content in Sugar Bean, Lentils and Groundnuts Sold By the Roadside in Gaborone, Botswana
}

\begin{tabular}{|l|}
\hline IJSRM \\
Ruth Gontse*1, Banyaladzi D. Paphane ${ }^{1}$, Tumisang \\
Papadi ${ }^{1}$ \\
Department of Physical and Chemical Sciences, \\
Botswana University of Agriculture and Natural \\
Resources, Private Bag 0027, Gaborone, Botswana. \\
Submission: $\quad$ 22 May 2020 \\
Accepted: $\quad$ 29 May 2020 \\
Published: $\quad$ 30 June 2020 \\
\hline
\end{tabular}
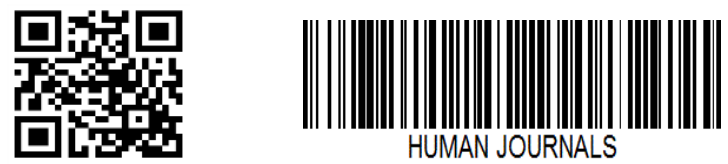

www.ijsrm.humanjournals.com
Keywords: Atomic Absorption, Legumes, Minerals, Heavy Metals

\section{ABSTRACT}

Samples of raw lentils, sugar beans and groundnuts were bought from a street vendor by the roadside at Gaborone Bus Station. Sample preparation was carried out by microwave digestion process. The digests were analyzed for selected metals $(\mathrm{Ca}, \mathrm{Fe}, \mathrm{Mg}, \mathrm{Zn}, \mathrm{Cd}$ and $\mathrm{Pb}$ ) using flame atomic absorption spectrophotometer (Varian Model 220 AAS). For the selected legumes, Lentils, Sugar beans and Groundnuts, mineral contents concentrations $(\mathrm{mg} / 100 \mathrm{~g}$ ) of $\mathrm{Ca}, \mathrm{Fe}, \mathrm{Mg}, \mathrm{Zn}$, together with that of heavy metals $\mathrm{Cd}$ and $\mathrm{Pb}$ were determined. Data analysis using Statistical Package for Social Scientists (SPSS) gave concentrations as follows: Lentils $(2.51 \pm 0.39,1.75 \pm 0.05,2.34 \pm 0.03,4,15 \pm 0.03)$, Sugar Beans ( $5.24 \pm 5.73,3.08 \pm 0.18,1.95 \pm 0.21,4.21 \pm 0.02$ ) , Groundnuts ( $5.65 \pm 0.12,1.93 \pm 0.32,2.49 \pm 0.11,4.33 \pm 0.05$ ) respectively for $\mathrm{Fe}, \mathrm{Mg}, \mathrm{Zn}$ and $\mathrm{Ca}$. $\mathrm{Cd}$ concentrations were very low recorded as $6.01 \times 10^{-5} \pm 1.85 \times 10^{-6}, 5.61 \times 10^{-5} \pm 3.57 \times 10^{-6}$ and $7.72 \times 10^{-5} \pm 8.44 \times 10^{-6}$ whereas for Lead $(\mathrm{Pb})$ were recorded as $8.35 \times 10^{-4} \pm 9.19 \times 10^{-6}, 1.94 \times 10^{-3} \pm 1.54 \times 10^{-3}$ and $2.61 \times 10^{-3} \pm 3.30 \times 10^{-4}$ respectively for the lentils, sugar beans and groundnuts. It is evident that the selected legumes have essential nutritional minerals even though appearing in lower concentrations, of which to some extend may compromise the nutritional quality of the samples. But as for possible contamination by toxic metals, there were no significant amounts recorded. 


\section{INTRODUCTION}

After cereals, legumes are the second most important source of human food and animal forage. The process of nitrogen fixation by legumes is very useful since there will be provide plant tissue that is high in protein. Legumes are used in agricultural practices as a way of curbing deficiency of nutrients of the planting soil. Most of the legumes are taken into diet because of their high content of dietary fiber, proteins and minerals such as potassium, calcium, phosphorus and magnesium. However, during food preparation, some water-soluble minerals can be leached and lost through drainage [1]. It has been evident that the significance of most of the legumes in agriculture and food security is increasing worldwide. Legumes are very important as they can fix nitrogen which is very useful for plant growth, this way giving them environmental and economic advantages [2]. Research indicated that high protein and water-soluble fiber have much benefit in reducing the risks of coronary heart disease and cardiovascular disease [3].

Groundnuts, or peanut (Arachis hypogaea L.), belong to the legume's family. Its origin is Mexico and America regions Groundnuts are very useful in production of various products for human consumption peanut butter, cakes and soups. Research has added the facts that the groundnut seeds samples are within the range of 40.10 to $42.13 \%$ fat, 24.48 to $26.37 \%$ crude protein, 4.24 to $6.30 \%$ carbohydrate and a significant amount of moisture, fiber and ash. Essential Minerals in groundnuts includes commonly known sodium, calcium, phosphorus, potassium, manganese, zinc, iron and copper. The dominant macro mineral element (potassium) could be recommended as source of dietary supplement. [4].

Lentils are some of the ancient legume plants which are consumed worldwide [5]. Lentils appear in different seed coat colours ranging from green, tan, brown, grey, white and black and they can have various patterns on the body [6]. Findings demonstrated that lentils are rich in fiber and low in fat [7]. Since lentils as a legume are sources of protein, there are other essential nutrients such as zinc, iron and vitamin B complex. Lentils have protein content of between $20.6 \%$ and $31.4 \%$ [8]. Literature also report that lentils have high antioxidant activity due to presence of phenolic compounds [9]. Children population in low -income countries are protein deficient and because of high protein content, fast cooking-time and increased production have led to lentils being among the legumes which are important in combating malnutrition and protein deficiency globally [10-11]. Lentil proteins are also a good source of bioactive peptides which have a lot of health benefits [12]. 
Bean consumption has increased in most countries especially developed one and beans have shown that they supply proteins, dietary fiber and vitamins which are important to human health. [13]. Speckled sugar bean is a grain legume, which is very nutritious and rich in protein. The grain is easily stored, making it a useful crop for subsistence use because it is a high-yielding variety with very acceptable seed appearance. It is also resistant to most known plant diseases. Protein extracted form Speckled sugar bean is nutritionally rich in proteins and micronutrients [14]. Different environmental factors such as temperature, production sites, agricultural practices and soil conditions may affect the protein content in common beans [15].

The determination of minerals and trace elements in foodstuffs is an important part of nutritional and toxicological analyses. Research on micro-mineral and anti-nutritional content of legumes and cereal based foods commonly consumed in Rwanda stated that due to prevalence of micro-nutrient deficiencies especially iron and zinc in many developing countries. Efforts are therefore being made to assess micro-nutrient content of foods to assess the extent of this deficiency [16]. Micronutrients such as copper, chromium, iron and zinc are very essential for human health since they help in human metabolism [17-18].

\section{Importance of minerals in the human body}

Chromium has a significant role in the metabolism of carbohydrates and lipids. When there is deficiency in $\mathrm{Cr}$, a sign of altered glucose tolerance is the most prevalent in the human body. The deficiency of this nutrient in the body has also been associated with increase in diabetes and cardiovascular diseases [19]. Dietary supplementation with $\mathrm{Cr}$ where there are frequent deficiencies have shown some beneficial effect [20].

Iron is an essential element; although iron metabolism occurs in a 'close circuit', there exist physiological losses which must be compensated for through iron supplements or through food rich in iron [21]. When there is insufficient Fe amount in the body, there is tendency for the occurrence of complications such as low blood, anemia, rickets and shortness of breath [21].

Metabolic processes including carbohydrate, lipid and protein synthesis or degradation involve zinc enzyme, which is required for deoxyribonucleic and ribonucleic acid synthesis and stabilizing plasma membranes [19]. Zinc is useful in the superoxide dismutase enzyme 
which is meant for prohibiting the oxidative processes. The daily intake for adults should be $12-15 \mathrm{mg}$.

The high presence and abundance of Aluminum in nature make it to be one of the minerals widely distributed in the whole food chain [22]. The toxicology and physiology studies for Aluminum is made difficult due to its ubiquity and contamination risks. This makes it too difficult for the scientific community to place it as a trace element which is essential for the human body [23]. Problems such as osteomalacia and neurodegenerative disorders (e.g. encephalopathy, dementia and Alzheimer's disease) has awakened interest in aluminum intake via the diet [24]. Normal intake ranges from 6 to $14 \mathrm{mg} /$ day. Estimated aluminum intake is reported to range from 0.7 and $11.5 \mathrm{mg} /$ day, and mean dietary intake varied between 2.5 and $6.3 \mathrm{mg} /$ day [25].

Other findings have shown that the lentil seeds contain many dietary essential minerals, such as sodium (65-81 mg/100 g), potassium (978-1024 mg/100 g), calcium (168-170 mg/100 g), magnesium (4.62-5.20 mg/100 g), phosphorus (301-341 mg/100 g),iron (6.6-7.3 mg/100 g), zinc (4.2-4.3 mg/100 g), copper (4.62-6.12 mg/100 g), and manganese (1.40-1.62 mg/100 g) [26].

\section{Mineral contamination}

Heavy metal contamination in the food chain is caused mainly by being environmental pollution. Lead and Cadmium metal contamination have aroused some concerns in research since contamination of the environment is increasing, and serious toxic effects develop due to the prolonged intake of even low concentrations of lead [27]. This has led to increased interest in determining lead levels in foodstuffs [28]. The total human lead intake supplied by the diet is approximately $80 \%$ [19]. Even though Cadmium element is naturally present in low concentrations in the environment, high levels are often associated with human activity and are mainly found in urban and industrial waste disposal. The toxicity of Cadmium is manifested by kidney dysfunction, hypertension, hepatic injury, reproductive toxicity, lung damage, bone effects, etc. [28].

Since this type of food products are in high demand, there are some practices such as application of fertilizers by farmers when trying to meet the demand which seem to indirectly increase the heavy metals in the soil which in turn can be transferred to crops growing in that soil [29]. Cd and Pd are common metals, which have shown some form of toxicity even when 
consumed at low quantities. And their use in the body is not known [30]. Consumption and intoxication of these metals is associated with diseases affecting the renal, cardiovascular, nervous and skeletal system [31-32]. It is necessary to account for contaminants, which might enter the food chain via many means such as industrial pollution, or environmental pollution. There is need for foods to be monitored for safety to ensure that levels of undesirable metals is below safe/ toxicity limits or not present at all [33].

The concentrations of minerals in samples is determined by technique Atomic Absorption Spectroscopy (AAS) which involves the absorption of light by free atoms of an element at a specific wavelength. This method is very sensitive and enables to detect small amounts. High analytical frequency, less costly operational facilities and good sensitivity make Flame Atomic Absorption Spectroscopy (FAAS) to bee of desirable characteristics in analysis. The quantification of heavy metals is done using atomic absorption spectroscopy techniques [34].

In this study, content of selected minerals was analyzed in sugar beans, lentils and groundnuts sold by the roadside as shown in figure 1 below, at the Gaborone Bus station in Gaborone, Botswana to investigate the possibility of heavy metal contamination due to human activity.
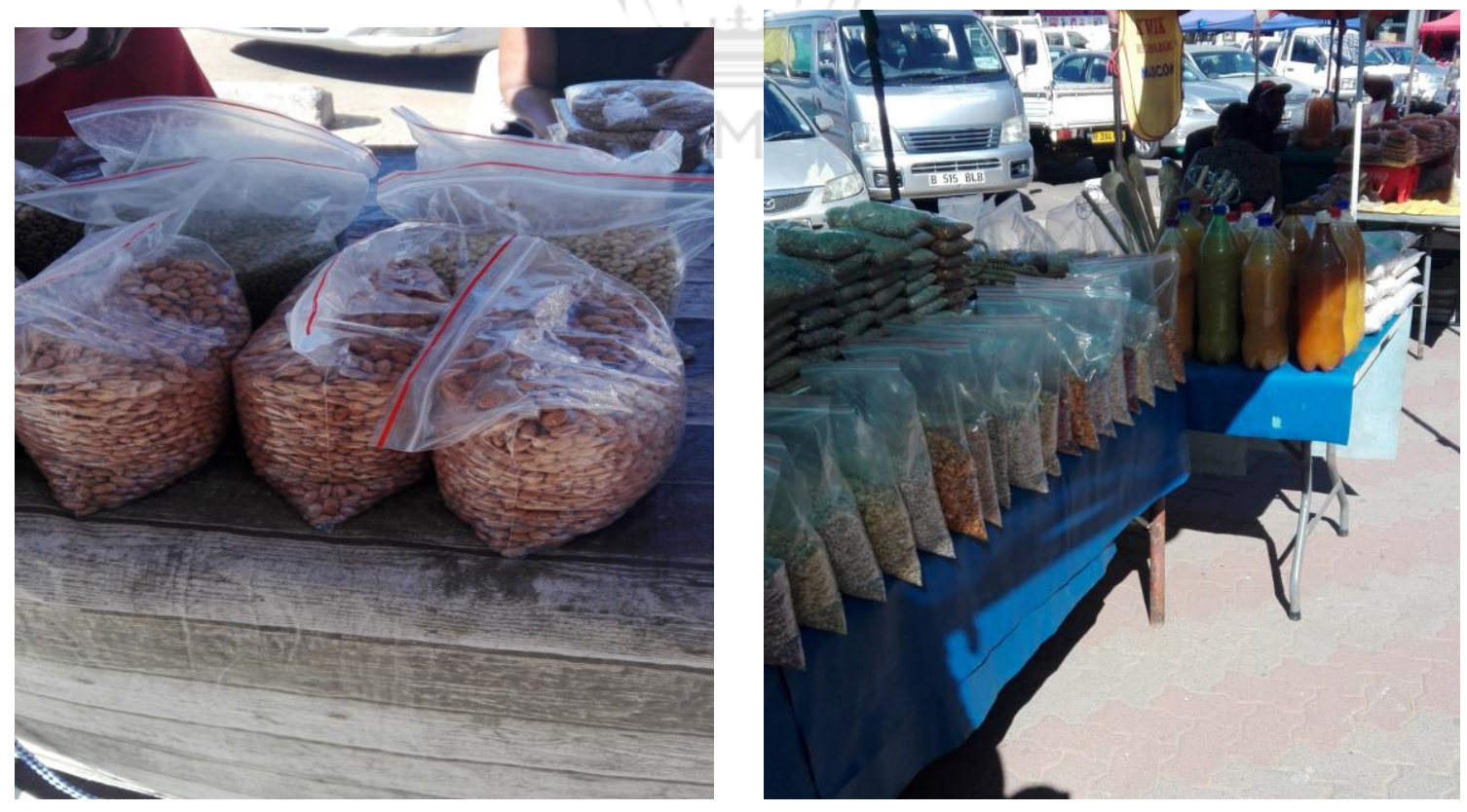

Figure No. 1: Typical marketplace on the roadside the by vendors in Gaborone 
www.ijsrm.humanjournals.com

\section{MATERIALS AND METHODS}

\section{Sample preparation}

Whole samples of raw lentils, sugar beans and groundnuts were collected from a street vendor near the road at Gaborone Bus Station (figure 1). The samples were packed into polyethylene bags, labeled and transported to the laboratory for further treatment. Upon arrival in the lab, the samples were separately ground using a miller which was continually decontaminated by brushing the miller and wiping with ethanol between samples. The powdered samples were then stored in clean clear glass bottles ready for the next procedures. Calcium, magnesium, zinc, and iron in the samples were determined by flame atomic absorption spectrometric method, while lead and cadmium were determined by graphite furnace atomic absorption spectrometric method.

\section{Microwave digestion}

A similar procedure was employed as for the procedures recommended by official methods of analysis, [35-36]. Approximately $0.3 \mathrm{~g}$ of each of the samples were weighed into sterilized digestion vessels. In a fume hood, $5 \mathrm{ml}$ of $65 \%$ Nitric acid $\mathrm{HNO}_{3}$ and $2 \mathrm{ml}$ of $35 \%$ Hydrogen Peroxide $\mathrm{H}_{2} \mathrm{O}_{2}$ were pipetted into all the samples and two empty digestion vessels as blanks respectively. After waiting for the samples to froth, the vessels were tightly closed. The rotor segment was inserted into the microwave cavity and the digestion program fully run for 51 minutes. Table 1 below show some of the digestion process parameters used. Upon completion of digestion program, the rotor was cooled by water until the solution reached room temperature. The solutions were filtered into sterilized $100 \mathrm{ml}$ volumetric flasks. To make analyte, the flasks were filled to the mark with ultra-pure water and finally transferred into $100 \mathrm{ml}$ plastic bottles for storage at $4^{0} \mathrm{C}$ ready for AAS analysis. 
Table No. 1: Temperature program used for digestion of lentils, sugar beans and groundnuts

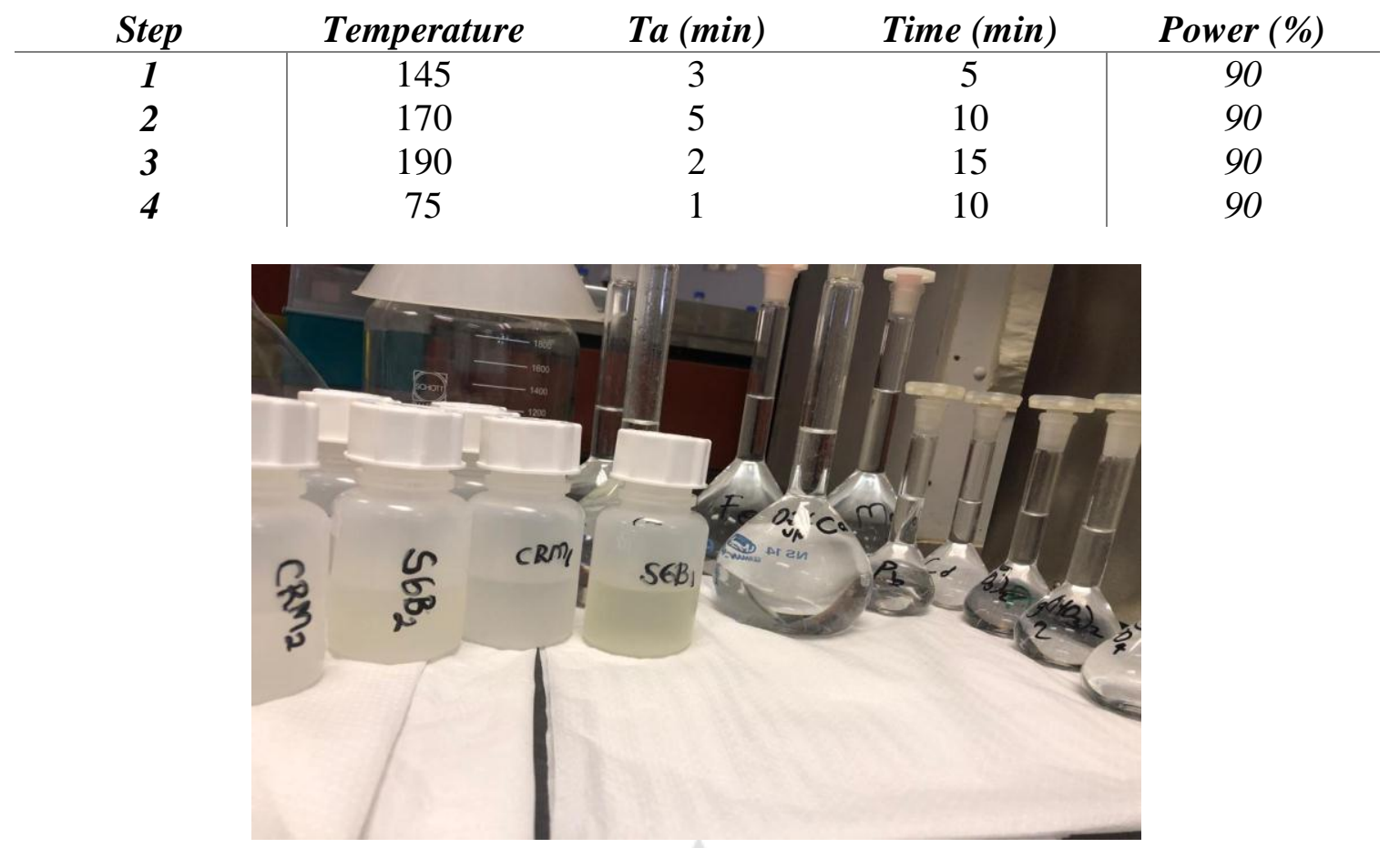

Figure No. 2: Samples of microwave digestion (analytes in plastic bottles) and prepared working standards

\section{Preparation of calibration standards}

High purity standards of concentrations of $1000 \mathrm{ppm}$ were used to prepare calibration standards into $250 \mathrm{ml}$ volumetric flasks. For Graphite Furnace Atomic Absorption Spectroscopy (GF-AAS) analysis of cadmium and lead, $50 \mathrm{ml}$ volumetric flasks were used. $1 \mathrm{ml}$ from the stock solution was transferred into $250 \mathrm{ml}$ volumetric flask and filled to the mark with ultra-pure water as shown in figure 2 above, and then the volumes were calculated from equating with individual stock solution concentrations. Table 2 below indicates the calculated volume of working standards and their concentrations. 
www.ijsrm.humanjournals.com

Table No. 2. Calculated volume of prepared working standards

Element standard

$\mathrm{Ca}$
$\mathrm{Mg}$
$\mathrm{Fe}$
$\mathrm{Zn}$
$\mathrm{Cd}$
$\mathrm{Pb}$

Concentration (ppm)

2

0.6

5

1

40

5
Volume $(\mathrm{ml})$

0.5

0.15

1.25

0.25

0.05

0.5

Determination of $\mathrm{Ca}, \mathrm{Mg}$, Fe and $\mathrm{Zn}$ by Flame Atomic Absorption Spectrophotometry (FAAS) and $\mathrm{Cd}$ and $\mathrm{Pb}$ by Graphite Furnace Atomic Absorption Spectrophotometry (GF-AAS)

$\mathrm{Pb}$ and $\mathrm{Cd}$ in foods generally require GF-AAS method for determination because of their lower concentrations. $\mathrm{Ca}, \mathrm{Mg}, \mathrm{Fe}$ and $\mathrm{Zn}$ were determined by flame AAS method using Atomic absorption Spectrophotometer with an air -acetylene burner, nitrous oxide-acetylene burner for flame and a graphite furnace (Varian Model 220 AAS) and micro test tubes for GF-AAS.

Wavelength, gas mixture/temperature program, and other instrumental parameters that are most appropriate for each metal were found in the manual provided with the instrument and set accordingly as shown in table 3 and 4 below. The appropriate element lamp was inserted into the lamp holder for each mineral. After setting up the instrument all parameters were checked, before switching on the instrument. Finally, absorbance of sample solutions and blanks were determined for individual minerals setting the instrument parameters afresh for each analysis. The instrument set up was changed for graphite method. The results were obtained in the Spectra Software for the instrument. Calibration curves from a minimum of 3 standards were prepared for both flame and graphite techniques. 
www.ijsrm.humanjournals.com

Table No. 3: Instrument parameters for $\mathrm{Ca}, \mathrm{Mg}, \mathrm{Fe}$ and $\mathrm{Zn}$ determination by FAAS

\begin{tabular}{|c|c|c|c|c|}
\hline Element & $\begin{array}{l}\text { Wavelength } \\
\text { (nm) }\end{array}$ & $\begin{array}{l}\text { Slit-width } \\
\quad(\mathrm{nm})\end{array}$ & Fuel & $\begin{array}{c}\text { Lamp } \\
\text { current }(m A)\end{array}$ \\
\hline$C a$ & 422.7 & 0.5 & $\begin{array}{l}\text { Nitrous oxide } \\
\left(\mathrm{N}_{2} \mathrm{O}\right)\end{array}$ & 10.0 \\
\hline$M g$ & 248.3 & 0.2 & Air/ Acetylene & 5.0 \\
\hline$F e$ & 285.2 & 0.5 & $\begin{array}{l}\text { Nitrous oxide } \\
\qquad\left(\mathrm{N}_{2} \mathrm{O}\right)\end{array}$ & 4.0 \\
\hline$Z n$ & 213.9 & 1.0 & Air/ Acetylene & 5.0 \\
\hline
\end{tabular}

Table No. 4: Instrument parameters for $C d$ and $P b$ determination by GT-AAS

\begin{tabular}{c|cclcc} 
Element & $\begin{array}{c}\text { Wavelength } \\
(\mathbf{n m})\end{array}$ & $\begin{array}{c}\text { Slit-width } \\
(\mathbf{n m})\end{array}$ & Fuel & $\begin{array}{c}\text { Lamp } \\
\text { current } \\
(\boldsymbol{m} \boldsymbol{A})\end{array}$ \\
\hline $\boldsymbol{C d}$ & 228.8 & 0.5 & Acetylene & 10.0 \\
$\boldsymbol{P b}$ & 283.3 & 0.5 & Acetylene & 10.0
\end{tabular}

\section{RESULTS}

Data was analyzed in triplicate using Statistical Package for Social Scientists (SPSS) software for windows. Independent sample t-test was used for comparison of means and significance accepted at 0.05 level of probability $(\mathrm{p}<0.05)$.

Table No. 5: Mineral contents (Ca, Fe, $\mathrm{Mg}, \mathrm{Zn}, \mathrm{Cd}$ and $\mathrm{Pb})$ of lentils, sugar beans and groundnuts (mg/100 $\mathrm{g}$ d.b) sold at Gaborone Bus station by the roadside

\begin{tabular}{|c|c|c|c|c|c|c|}
\hline Sample & Calcium & Iron & Magnesium & Zinc & Cadmium & Lead \\
\hline Lentils & $4.15^{\mathrm{a}} \pm 0.03$ & $2.51^{\mathrm{a}} \pm 0.39$ & $1.75^{\mathrm{a}} \pm 0.05$ & $2.34^{\mathrm{a}} \pm 0.03$ & $\begin{array}{c}0.0000601^{\mathrm{a}} \\
\pm 0.00000185\end{array}$ & $0.000835^{\mathrm{a}} \pm 0.00000919$ \\
\hline $\begin{array}{l}\text { Sugar } \\
\text { beans }\end{array}$ & $4.21^{\mathrm{ab}} \pm 0.02$ & $5.24^{\mathrm{a}} \pm 5.73$ & $3.08^{\mathrm{b}} \pm 0.18$ & $1.95^{\mathrm{a}} \pm 0.21$ & $\begin{array}{c}0.0000561^{\mathrm{a}} \\
\pm 0.00000357\end{array}$ & $0.00194^{\mathrm{a}} \pm 0.00154$ \\
\hline Groundnuts & $4.33 b \pm 0.05$ & $5.65^{\mathrm{a}} \pm 0.12$ & $1.93 \mathrm{a} \pm 0.32$ & $2.49^{\mathrm{a}} \pm 0.11$ & $\begin{array}{c}0.0000772^{\mathrm{a}} \\
\pm 0.00000844\end{array}$ & $0.00261^{\mathrm{a}} \pm 0.000330$ \\
\hline
\end{tabular}

Values expressed as means of the analysis of two independent samples analyzed in duplicate $(\mathrm{n}=2) \pm 1 \mathrm{SD}$

ab - Values with different superscripts differ significantly $(\mathrm{p} \leq 0.05)$ 


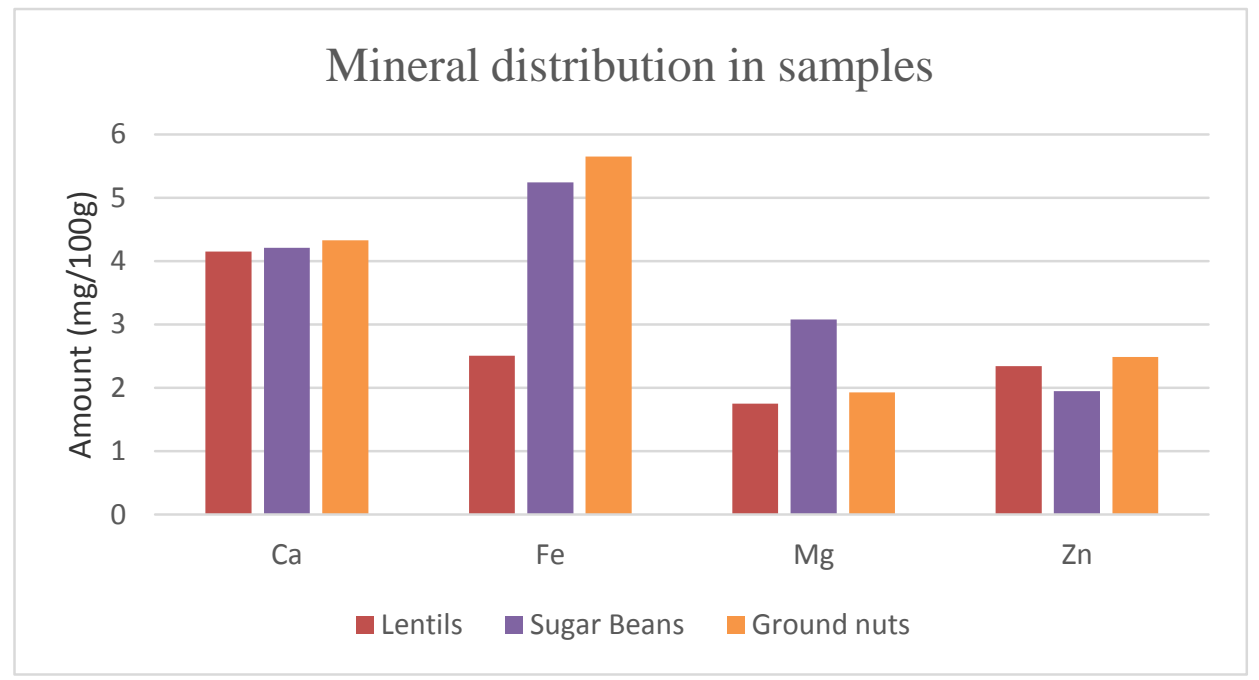

Figure No 3: Distribution of essential minerals in lentils, sugar beans and groundnuts sold at Gaborone Bus station by the roadside

\section{DISCUSSION}

Results show a significant variation of mineral concentrations in lentils, sugar beans and groundnuts. Using a probability level of 0.05 , table 5 shows the significance levels of the minerals $(\mathrm{Ca}, \mathrm{Fe}, \mathrm{Mg}$ and $\mathrm{Zn}$ ) together with the two heavy metals ( $\mathrm{Cd}$ and $\mathrm{Pb}$ ) with relevance to p-values. Values with different superscripts differ significantly. The results in table 5 indicates that there is no significant difference in $\mathrm{Ca}, \mathrm{Fe}, \mathrm{Mg}, \mathrm{Zn}$ and $\mathrm{Cd}$ and $\mathrm{Pd}$ contents in most of the samples. However only $\mathrm{Ca}$ and $\mathrm{Mg}$ content of sugar beans showed a significant difference between samples. The values for calcium content ranges from $4.15 \pm 0.03$, $4.21 \pm 0.02$ and $4.33 \pm 0.05 \mathrm{mg} / 100 \mathrm{~g}$ in lentils, sugar beans and groundnuts respectively. The iron content is $2.51 \pm 0.39,5.24 \pm 5.73$ and $5.65 \pm 0.12 \mathrm{mg} / 100 \mathrm{~g}$, magnesium content is $1.75 \pm 0.05,3.08 \pm 0.18$ and $1.93 \pm 0.32 \mathrm{mg} / 100 \mathrm{~g}$, zinc amount is $2.34 \pm 0.03,1.95 \pm 0.21$ and $2.49 \pm 0.11$ in lentils, sugar beans and groundnuts respectively.

Moreover, the heavy metal amounts show very low concentrations ranging from $6.01 \times 10^{5}$ to $7.72 \times 10^{5} \mathrm{mg} / 100 \mathrm{~g}$ for cadmium in lentils and groundnuts, the lowest concentration for lead was recorded in groundnuts at $2.61 \times 10^{3} \mathrm{mg} / 100 \mathrm{~g}$. According to Codex standards for contaminants and toxins in food and feed, $0.2 \mathrm{mg} / \mathrm{kg}$ is the level considered toxic when reached in foods. From the results obtained in the experiments, cadmium and lead content in all the samples is less than the toxicity level. 
www.ijsrm.humanjournals.com

Table No. 6: Comparison of mineral content of lentils, sugar beans and groundnuts sold at

Gaborone Bus Station with nutritional composition tables from

https://www.nutritionvalue.org/ (mg/100g)

\begin{tabular}{lcccccc}
\hline & LENTILS & \multicolumn{3}{c}{$\begin{array}{c}\text { SUGAR } \\
\text { BEANS }\end{array}$} & \multicolumn{3}{c}{$\begin{array}{c}\text { GROUND } \\
\text { NUTS }\end{array}$} \\
\hline MINERALS & Literature & ExpResults & Literature & ExpResults & Literature & ExpResults \\
\hline Iron & 6.51 & $2.51 \pm 0.39$ & 6.69 & $5.24 \pm 5.73$ & 4.58 & $5.65 \pm 0.12$ \\
\hline Magnesium & 47.00 & $1.75 \pm 0.05$ & 138.00 & $3.08 \pm 0.18$ & 168.00 & $1.93 \pm 0.32$ \\
\hline Zinc & 3.72 & $2.34 \pm 0.03$ & 2.79 & $1.95 \pm 0.21$ & 3.27 & $2.49 \pm 0.11$ \\
\hline Calcium & 35.00 & $4.15 \pm 0.03$ & 83.00 & $4.21 \pm 0.02$ & 92.00 & $4.33 \pm 0.05$ \\
\hline
\end{tabular}

Figure 3 above illustrates the pictorial distribution of minerals across samples with groundnuts showing the highest concentrations in all the minerals except for magnesium. Sugar beans show relatively the highest amount of magnesium across all samples. The calcium concentrations of samples are almost the same. In comparison with standard values from [37], the obtained values for calcium and magnesium are very different. From the site, calcium amount in lentils, sugar beans and groundnuts are 35, 83 and 92mg/100g respectively compared to $4.15,4.21$ and $4.33 \mathrm{mg} / 100 \mathrm{~g}$ respectively. Similarly, magnesium amounts differ with literature values. These differences might be because of soil type, contamination, interferences or cultivar difference not forgetting some handling and environmental exposure issues. As for zinc and iron the results are very close to values obtained from literature as shown in table 6 . In lentils, $2.51 \mathrm{mg} / 100 \mathrm{~g}$ was obtained whilst raw lentils are expected to contain $6.51 \mathrm{mg} / 100 \mathrm{~g}$ of iron, zinc also shows a slight difference having obtained $2.34 \mathrm{mg} / 100 \mathrm{~g}$ zinc compared to $3.72 \mathrm{mg} / 100 \mathrm{~g}$ expected in raw lentils. For sugar beans, the amounts of iron and zinc obtained are 5.24 and $1.95 \mathrm{mg} / 100 \mathrm{~g}$ respectively, these also are in close range to 6.69 and $2.79 \mathrm{mg} / 100 \mathrm{~g}$ respectively for mature seeds of the beans as taken from www.nutritionvalue.org. Groundnuts also show a similar trend having iron and zinc amounts of 5.65 and $2.49 \mathrm{mg} / 100 \mathrm{~g}$ compared to 4.58 and $3.27 \mathrm{mg} / 100 \mathrm{~g}$ iron and zinc amounts respectively. Interestingly, amount of iron for groundnuts sold at Gaborone Bus station is slightly higher than that from literature by $1.07 \mathrm{mg} / 100 \mathrm{~g}$. 


\section{CONCLUSION}

In this piece of investigation, the analysis of trace elements $\mathrm{Zn}, \mathrm{Fe}, \mathrm{Mg}$ and $\mathrm{Ca}$ was done by AAS analysis method. The study shows that the lentils, sugar beans and groundnuts sold by the roadside of Gaborone Bus rank have nutritional minerals. Even though the minerals are present, they are in lower quantities compared to literature values. This indicates poor nutritional quality of the samples. The low amounts of mineral content somehow should not be of a hindrance in the consumption of these types of products since they have proven to be the preferred sources of protein in the food chain for local communities. The slight discrepancies in the amounts of minerals in question for respective legumes from literature values might be due to longer periods of storage, harsh ploughing conditions in the region, poor handling during harvesting and storage and exposure to environmental pollutants. However, there are no significant amounts of heavy and toxic metals as Lead and Cadmium contamination to be a cause for alarm. Food sold along the roadside are at times associated with serious contamination from fumes and other pollutants from automobiles due to prolonged exposure. This study has shown that the legumes sold by roadside vendors at Gaborone bus rank are not greatly affected. This might be because sellers only bring stock that is only enough to be sold out within a day hence reducing the exposure of these legumes to vehicle exhaust fumes.

\section{ACKNOWLEDGEMENTS}

The authors would like to sincerely thank Botswana University of Agriculture and Natural Resources and National Food Technology Research Center for availing laboratory space and instrumentation to carry out this study. Technicians and academic staff from these two organizations are greatly acknowledged for their valuable assistance.

\section{REFERENCES}

1. Ayoola, P. B, Adeyeye, A. and Onawumi, O. O. 2012. Chemical evaluation of food value of groundnut (Arachi hypogaea L.) seeds, American Journal of Food and Nutrition, ajfn.2012.2.3.55.57

2. Krishnan, H. B. and Coe, E. B., Jr. Seed storage proteins. In Encyclopedia of Genetics; Science Direct: Amsterdam, The Netherlands, 2001; pp. 1782-1787.

3. Bazzano L.A., HeJ., Ogden L.G., Loria C., Vupputuri S., Myers. L. and Whelton P.K, Legume consumption and risk of coronary heart diseases in US men and women. Arch Intern Med. 2001, 161(21); 2573-2578

4. Asibuo, J.; Akromah, R.; Adu-Dapaah, H. K. and Safp- Kantanka, O. Evaluation of Nutritional Quality of Groundnut (Arachis hypogaea L.) from Ghana. AJFAND .2008. Vol 8 Num 2 (ISSN: 1684-5358), 133-150.

5. Nosworthy, M.G.; Neufeld, J.; Frohlich, P.; Young, G.; Malcolmson, L. and House, J. D. Determination of the protein quality of cooked Canadian pulses. Food Sci. Nutr. 2017, 5, 896-903. 
6. Vandenberg, A. and Slinkard, A. E. Genetics of seed coat color and pattern in lentil. J. Hered. 1990, 81, 484488.

7. Brummer, Y., Kaviani, M. and Tosh, S. M. 2015. Structural and, functional characteristics of dietary fibre in beans, lentils, peas and chickpeas. Food Research International, 67, 117-125.

8. Urbano, G., Porres, J. M., Frıas, J. and Vidal-Valverde, C. 2007. Chapter 5 nutritional value In Lentil: An Ancient Crop for Modern Times. (edited by S.S. Yadav, D. McNeil \& P.C. Stevenson) p. 47-93. Vol. 3. Berlin: Springer.

9. Grela, E.R.; Kiczorowska, B.; Samoli' nska, W.; Matras, J.; Kiczorowski, P.; Rybi ' nski, W. and Hanczakowska, E. Chemical composition of leguminous: Part I-Content of basic nutrients, amino acids, phytochemical compounds and antioxidant activity. Eur. Food Res. Technol. 2017, 243, 1385-1395.

10. Semba, R. D. The rise and fall of protein malnutrition in global health. Ann. Nutr. Metab. 2016, 69, 79-88. 11. Arsenault, J.E. and Brown, K.H. Effects of protein or amino-acid supplementation on the physical growth of young children in low-income countries. Nutr. Rev. 2017, 75, 699-717.

12. Hamid Khaziel, Seed protein of lentils: current status, progress and food applications, a review, Foods Journal, 2019, 8, 391

13. Lucier, G.; Lin, B. H; Allshouse, J. and Kantor, L. S. Factors affecting dry bean consumption in the United States. Small 2000, 19, 2-5

14. Wortman, S. C., Kirkby, A. R., Eledu, A. C., and Allen, J. D. (Eds.). 2004. Atlas of common bean (Phasealus vulgaris L.) production in Africa. Cali, Colombia: International Centre for Tropical Agriculture, CIAT.

15. Florez, A.; Pujola, M.; Valero, J.; Centelles, E.; Almirall, A. and Casanas, F. Genetic and environmental effects on chemical composition related to sensory traits in common beans (Phaseolus vulgaris L.). Food Chem 2009, 113, 950-956

16. Ongol P. (2014). Micro-mineral and anti-nutritional content of legumes and cereal based foods commonly consumed in Rwanda: University of Rwanda, College of Agriculture, Animal Sciences and Veterinary Medicine, Kigali, Rwanda

17. Pelus E, Arnaud J, Ducros V, Faure H, Favier A and Roussel A.M. Trace element (Cu, Zn, Fe, Mn, Se) intakes of a group of French men using the duplicate diet technique. Int. J Food Science and, Nutrition.1994,45:63-70.Available[online]@

https://www.ajol.info/index.php/ajce/article/viewFile/105529/95550; accessed on 31/ 08/2018

18. Fennema O.R. Food Chemistry. New York: Marcel Dekker 2000.

19. Shils M. E, Olson J. A and Shike M 2012. Modern nutrition in health and disease. Available online@ https://www.ajol.info/index.php/ajce/article/viewFile/105529/95550 [accessed] on 24/08/2018

20. Van Cauwenbergh R., Hendrix P., Robberecht H. and Deelstra H.A. Daily dietary chromium intake in Belgium, using duplicate portion sampling. Z Lebensm Unters Forsch 1996; 203: 20

21. Hallberg L, Hulthen L, Garby L. Iron stores in man in relation to diet and iron requirements. Eur J. Clin Nutr 1998;52: 623-631

22. Gerhardsson L. Oskarsson A. and Skerfving S. 2009.Acid precipitation effects on trace elements and human health. Sci Total Environ 1994; 153:237 -245

23. Seiler H.G., Sigel A. and Sigel H. Handbook on metals in clinical and analytical chemistry. New York Marcel Dekker, 1994 to add pages

24. Massey R. C. and Taylor D 1999. Aluminium in food and the environment. London: Royal Society of Chemistry

25. Pennington J.A and Schoen S. A 1995 Estimates of dietary exposure to aluminium.; 12:119 -128

26. Campbell-Platt, 2009: Food Science and Technology, Wiley-Blackwell Publication Ltd, UK

27. Concon, J.M. Food Toxicology: contaminants and additives. New York: Marcel Dekker, 1988.

28. Cabrera, C., Lorenzo M.L., Gallego C, Lopez M.C. and Lillo E. Determination of lead in fish by electrothermal atomic absorption spectrometry. Anal Chim Acta 1991; 246:375- 378.

29. Alloway, B. J. 1995.Heavy metals in soils, Blackie academics professional publishers, London 7-39.

30. Lidia, G. L. C., Sylvia, R. M., and Lilliana, M. 1997. Heavy metals input with phosphate fertilizers used in Agerntina. Science of the Total Environment, 204: 245-250. 


\section{www.ijsrm.humanjournals.com}

31. Steenland, K. and Boffetta, P. 2000.Lead and cancer in humans: where are we now? American Journal of Industrial Medicine, 38: 295-299.

32. Jarupa, L.2003. Hazards of heavy metal contamination. British Medical Bulletin, 68: 167-182. Kalixp amphetamine-Like effects in humans of Khat alkaloid Cathinone 1990.

33. Zuliani, T., Kralj, B., Stibilj, V. and Milac ${ }^{` i c}{ }^{`}$, R., 2005. Minerals and trace elements in food commonly consumed in Slovenia. Italian Journal of Food Sciences 17, 155-166

34. Citak D., Tuzen M. and Soylak M. 2009, Simultaneous coprecipitation of lead, cobalt, copper, cadmium, iron and nickel in food samples with zirconium (IV) hydroxide prior to their flame atomic absorption spectrometric determination. Food and Chemical Toxicology, 47, 2302-2307

35. AOAC (1990) AOAC Official Methods of Analysis, $15^{\text {th }}$ ed. Arlington, Virginia 84-85

36. Akram S., Najam R., Rizwani G. H. and Abbas S.A. 2015. Determination of heavy metal contents by atomic absorption spectroscopy (AAS) in some medicinal plants from Pakistani and Malaysian origin, Pak. J. Pharm. Sci., 28, 1781-1787.

37. Nutrition value, 2020, https://www.nutritionvalue.org, 